\title{
Innovative and Technology-Enhanced Learning Approaches for Older Adults
}

\author{
SONIA HETZNER \\ Innovation in Learning Institute, Friedrich-Alexander-University Erlangen-Nuremberg, Germany \\ Sonia.hetzner@ili.fau.de \\ ELINE LEEN \\ Innovation in Learning Institute, Friedrich-Alexander-University Erlangen-Nuremberg. Germany \\ eliene.leen@ili.fau.de
}

\begin{abstract}
As adult learners, and especially learners older than sixty years of age, are a very heterogenic group, it is challenging to create learning concepts which suit the entire group and respect particular needs. E-learning can be a solution, as it is possible to learn very individually but still as part of a learning community when participating in an e-learning course. E-learning courses for older adults about ICT learning have revealed that this can be a very successful way of learning as long as some didactical principles are fulfilled, and communication and support is offered to the learner. This article describes some basic guidelines for successful ICT courses for older adults and offers a solution for older adults who still have negative feelings towards using ICT. With the possibilities of mobile learning, ICT literacy acquisition becomes even easier as tablet use requires less technology skills than the use of a standard computer. As first results of mobile learning for older adults are very promising, a new European project offers learning material for unexperienced users in four European countries. This project is also introduced in this article.
\end{abstract}

Keywords: e-learning, mobile learning, adult learners, older learners, tablets.

\section{Resumen}

Dado que los alumnos adultos (y especialmente los alumnos mayores de sesenta años) son un grupo muy heterogéneo, es un reto crear conceptos de aprendizaje que se acoplen a la totalidad del grupo y respeten las necesidades particulares. El aprendizaje en línea puede ser una solución, pues posibilita un método de aprendizaje muy individualizado pero sin dejar de formar parte de la comunidad de alumnos que participan en un curso de estas características. Los cursos en línea para el aprendizaje de las TIC destinados a la tercera edad han revelado que este puede ser un modo muy adecuado de aprendizaje, siempre que se cumplan ciertos principios didácticos y que se ofrezca comunicación y apoyo al alumno. Este artículo describe algunas directrices básicas para la idoneidad de cursos sobre las TIC destinados a las personas mayores, y ofrece una solución para esa parte de la tercera edad que mantiene todavía ideas negativas hacia el uso de dichas TIC. Con las posibilidades de aprendizaje que brindan los dispositivos móviles, la adquisición de conocimientos sobre las TIC se facilita aún más, pues el uso de una tableta requiere menos destrezas tecnológicas que el uso de un ordenador estándar. Dado que los primeros resultados del aprendizaje a través de dispositivos móviles para la tercera edad son muy prometedores, un nuevo proyecto europeo ofrece material de aprendizaje para usuarios sin experiencia previa en cuatro países europeos. El presente artículo da a conocer también ese proyecto.

Palabras clave: aprendizaje en línea, aprendizaje mediante dispositivos móviles, alumnos adultos, alumnos de la tercera edad, tabletas. 


\section{Adult learners: a very heterogenic group}

Creating learning approaches and offers for adults is a challenging task for researchers and trainers. Adults are a very heterogenic group, especially when we are talking about older adults. They differ not only in learning speed, the adequate use of learning strategies and memory performance, but they also have very different previous learning experiences and histories and, based on this, different attitudes against or in favor of learning. For example, people who do not engage in learning frequently, see learning activities more negative and exhausting than people who consider themselves as active learners (Kolland \& Ahmadi, 2010). This has of course an impact on motivation for learning, which is a very important part of learning in adult life, as learning is very often a voluntary activity.

Motivation for learning is different for adults compared with children and there are also differences between younger and older adults, e.g. the intrinsic and personal growth components increase with age (Grube \& Hertel, 2008; Leen \& Lang, 2013). This means, when adults get older, intrinsic motives like the urge to learn because of own interests and individual fulfillment become more and more important compared to motives from outside which are important for younger persons, like good grades, a good job perspective or reputation and prestige earned by learning (Heckhausen \& Heckhausen, 2006). Also comparisons and competition become less attractive with older age (Mayr, Wozniak, Davidson, Kuhns \& Harbaugh, 2011).

Besides the motivation to learn voluntarily, it is important to take the principles of andragogy (Knowles, Holton \& Swanson, 1998) into account when the learning system and material is designed. These are: relevance of the learning material to real world experiences, the need to know what to learn and why, the learning goals need to be in line with goals of the learner and individual differences need to be respected. Furthermore, the learning situation should trigger intrinsic motivation, foster selfdirected learning and help the learner to set their own learning path and agenda in the background of their own learning experience.

All these aspects are important for all adult learners, but when we are talking about older adults above 60 years of age, additional learning differences can occur: some have impairments like sensory, audition and vision problems. Memory differences in this age group are bigger and also simple motor coordination for the use of a computer mouse can be a big challenge. Nevertheless, learning can also benefit those older adults, who already show some declines, as even in older age neuronal plasticity still exists (Lindenberg \& Kray, 2005).

When we keep all these differences between learners in our mind, we have to ask ourselves: How can we design useful learning material which takes these many degrees of freedom into account?

\section{Innovative e-learning solutions for older adults}

The answer is very simple. By using innovative technologies, people can learn self-directed, in their own speed and time, but can also benefit from various support functions that guarantee some guidance, support and communication. This means, e-learning or blended learning formats can contribute to all these challenges and can help to teach heterogeneous groups of adults when some basic principles are fulfilled.

One of the most important aspects is that mentoring and tutoring should always be a key element in all e-learning courses, but especially for older adults as some need more guidance. Well-educated tutors who can support and motivate individually are very important for the success of learning and for completing courses (Hetzner \& Leen, 2013). Other studies with online courses for older adults show that it is important to have free timeslots and the possibility to choose the own learning speed, but also some structure and the feeling of learning together in a group or learning community (social learning) (Hetzner $\&$ Held, 2009). E-learning should always come to the people and not vice-versa; the courses should be adapted to the daily living circumstances of the target group so that the learner can easily recognize the added value of learning (Friebe, 2009). Furthermore, many rehearsal possibilities should be given to the learner and new material should be connected with prior life experiences (Nuissl, 2009). Aside of the communication with tutors with different media (e-mail, forum, skype, chat), the learners should also communicate with and support each other. Con- 
cepts with peer-to-peer teaching and tutoring are also promising, as long as the tutors are specially trained (Karl, 2009; Hetzener \& Leen, 2013). Additionally, for the group of older learners, it is important not to overload them with information and technology. The technology should be as easy as possible, but of course it should train them to find their ways in the «real ICT world». To reach this goal, it can help to let them practice on their own devices and rehearse very often and to offer different media approaches with the same content (audio and text for example) to fulfill the needs of different learning types and give them many exercises to work with different multimedia-enriched didactical elements. As already stated above, motivation is also a key element for learning success. To enhance learning motivation, motivating examples of other learners, informal learning methods and problem-based learning should also be integrated.

That these concepts are very successful to teach ICT basics to older adults was shown in previous European and national projects, like the eLSe project, eLSe academy and Learn@Haus (Hetzner \& Held, 2009; Coroian, Held \& Schüring, 2012). Started in 2004 during these projects, basic and advanced e-learning courses for older adults were developed and taught them how to take their first steps on the Internet and on a computer. In a basic course, participants learned, for example, how to write e-mails, find basic information online, write letters and organize documents on a computer. In the advanced course, people learned e.g. how to communicate with skype and forums, how to process some images and create simple presentations. All learning activities took place online, except for a first face-to-face session to learn the very first steps e.g. how to switch on a computer. In the last ten years, ca. 900 older adults in Germany, Italy, Spain, Sweden and Lithuania successfully finished online courses based on the eLSe and Learn@Haus concepts.

Additionally, based on the described pedagogical and didactical principles, two European projects which facilitate intergenerational learning and online exchange between different target groups and go beyond ICT competencies were developed and were also very successful. Both projects facilitated the active participation of older adults as part of the information and knowledge society. One project (HiStory) offered information about Web 2.0 techniques to older adults and taught them how to blog about historical events as eye witnesses so that younger interested persons can learn from these experiences (www.history-project.eu). The other initiative, e-Vita (Hetzner and Pannese, 2009) developed an innovative and unique approach for the development of Serious Games starting from Storytelling techniques to promote knowledge sharing and intergenerational learning. Younger generations are supported to directly «live» some experiences that older adults have lived before the European Union was established. Thus, the complexity of the past can be directly experienced and understood through a game that shows how life was at that time.

\section{The next step: Older adults learn with mobile devices}

Although these course concepts were very successful, there are still many older adults who are afraid of using a computer or are not motivated to invest time and effort into learning some basic ICT competences. For this group, mobile learning with tablet computers can be an attractive solution. In 2012, Werner and Oberzaucher showed in their research, that tablet computers reach high acceptance and satisfaction rates for new, unexperienced users. Also the eLSe and Learn@Haus concepts were transferred to a small course for mobile learning in 2013 and in a comparison study with two groups of older adults, the group who used tablet computers instead of laptops showed a faster learning curve and gained the same competences as the laptop group but in a much shorter time period (Hetzner, Tenckhoff-Eckhardt, Held \& Slyschak, 2014; Hetzner, Tenckhoff-Eckhard \& Held, 2013). The tablet group was very motivated and the touch concept has advantages compared to the more complex use of mouse and keyboard.

Based on these promising findings, a new European Erasmus plus project, SenApp, started 2014 in four countries (www.senapp.eu ). In Spain, France, Romania and Germany, learning units for tablet computers are designed as small applications and will be tested in autumn 2015 in four languages. First research results have already shown that this concept has many benefits for older adults. They are very simple to use and the mobile devices are easy 
to take with you wherever you want. They are fast to use due to low starting times, they are also usable with a low level of e-skills and, with the app concept, the different tasks are very fast to reach and the touch screen is very easy to understand. With the help of mobile learning, ICT literacy of older adults will hopefully increase in the next years.

\section{Discussion}

During the last years, the numbers of active ICT users are growing, also in the older age groups. However, in the age group above 70 years of age, there are still many non-users. For example, in Germany, only $29.4 \%$ use the Internet on a regular basis (Initiative D21, 2014). The main reason for non-liners is that they see no added value to other media and therefore they seem not to need the Internet or computers in general (Gerhards \& Mende, 2009). But also fear of technology can be a reason, especially for women. Women also report more negative feelings against computers and the Internet (Broos \& Roe, 2005). The group of older women who are not using a computer is also very stable during the last couple of years and they are hard to reach and persuade.

However, with new approaches like mobile learning, which requires less technology skills and is easy to use, some new users, especially women, might be persuaded. As the use of computers and the Internet can have some benefits on quality of life for older adults, e.g. by learning new possibilities for more social interactions (Schweiger \& Ruppert, 2009), especially for those who are mobility restricted or live in rural areas, it seems useful to try to motivate more older adults to become active users. It might be impossible to reach all older adults, and not all will benefit from ICT, but it is important to give everybody the opportunity to become not excluded from new technologies.

\section{References}

Broos, A. \& Roe, K. (2005). Marginality in the information age: Is the gender gap really diminishing? Communications, 30, 251-260. doi:10.1515/comm.2005.30.2.251.

Coroian, E., Held, P. \& Schüring, L. (2012).Lern@Haus. Nie zu alt fürs Internet. Dokumentation \& Evaluation. Bundesministerium für Familien, Senioren, Frauen und Jungend. http://www.programm-altersbilder. de/fileadmin/user_upload/dokumente/LernHaus-Bericht-final-120828.pdf Accessed on 10 July 2015.

Friebe, J. (2009). Bildung bis ins hohe Alter? Anspruch und Wirklichkeit des Weiterbildungsverhaltens älterer Menschen in Deutschland. Deutsches Zentrum für Erwachsenenbildung. www.die-bonn.de/doks/friebe0901. pdf Accessed on 10 July 2015.

Gerhards, M. \& Mende, A. (2009). Offliner: Ab 60-jährige Frauen bilden die Kerngruppe. Media Perspektiven, 7, 365-376.

Grube, A. \& Hertel, G. (2008). Altersbedingte Unterschiede in Arbeitsmotivation, Arbeitszufriedenheit und emotionalem Erleben während der Arbeit. Wirtschaftspsychologie, 3, 18-29.

Heckhausen, J. \& Heckhausen, H. (2006). Motivation und Handeln. Heidelberg: Springer Medizin Verlag.

Hetzner, S. \& Held, P. (2009). E-Learning for Senior Citizens. In: U. Bernath (Ed.), Distance and e-learning in transition (pp.335-348). London: ISTE Willey.

Hetzner, S. \& Leen, E. (2013). Personalisation and Tutoring in E-Learning: The Key for Success in Learning in Later Life. European Journal of Open, Distance and E-Learning, Special Issue: Best of EDEN 2012, 14-25.

Hetzner, S. \& Pannese, L. (2009). E-Vita, life simulations in an Intergenerational Setting. Journal of e-learning and Knowledge society 5,59-65.

Hetzner, S., Tenckhoff-Eckhardt, A. \& Held, P. (2013). The Joy of Learning in Later Life. Preoceedings of the EDEN-Conference 2013.

Hetzner, S., Tenckhoff-Eckhardt, A., Held, P. \& Slyschak, A. (2014). Promoting Digital Literacy for Seniors, the aptitude of tablet-pcs. eLearning Papers , 38(Digital Literacies and eCompetence). 
Initiative D21 (2014). (N)onliner Atlas 2014. http://www.initiatived21.de/portfolio/nonliner-atlas/ Accessed on 10. July 2015.

Karl, F. (2009). Einführung in die Generationen- und Altenarbeit. Opladen: Verlag Barbara Budrich.

Knowles, M. S., Holton III, E. F. \& Swanson, R. A. (1998). The Adult Learner. Houston, Texas: Gulf Publishing Company.

Kolland, F. \& Ahmadi, P. (2010). Bildung und aktives Altern. Bielefeld: W. Bertelsmann Verlag.

Leen, E. A. E. \& Lang, F. R. (2013). Motivation of computer based learning across adulthood. Computers in Human Behavior, 3, 975-983, doi: 10.1016/j.chb.2012.12.025

Lindenberg, U. \& Kray, J. (2005). In S.-H. Filipp \& U. M. Staudinger (Eds.), Entwicklungspsychologie des mittleren und höheren Erwachsenenalters (pp. 300-341). Göttingen: Hogrefe.

Mayr, U., Wozniak, D., Davidson, C., Kuhns, D. \& Harbaugh, W. T. (2011). Competitiveness across the life span: The feisty fifties. Psychology and Aging, 27, 278-285. doi:10.1037/a0025655

Nuissl, E. (2009). Professionalisierung in der Altenbildung. In: U. M. Staudinger. \& H. Heidmeier, H. (Eds.), Altern, Bildung und lebenslanges Lernen (pp. 95-102). Halle (Saale):Deutsche Akademie der Naturforscher.

Schweiger, W. \& Ruppert, A. K. (2009). Internetnutzung im höheren Lebensalter - Lebensglück, Alterserleben und die unerkannte Problemgruppe, Männer'. In: B. Schab, A. Hartung \& W. Reißmann (Eds.), Medien und höheres Lebensalter. Theorie - Forschung - Praxis (pp. 171-186). Wiesbaden: VS.

Werner, F., Werner, K. \& Oberzaucher, J. (2012). Tablets for Seniors - An evaluation of a current model (Ipad). Ambient Assisted Living. Series: Advanced Technologies and Societal Change, 177-184. doi: 10.1007/9783-642-27491-6_13. 